\section{US healthcare: take a number, please}

Passed by the US Congress in 1996, the Heal th Insurance Portability and Accountability Act (HIPAA) contained a littlenoticed provision requiring that every American citizen be assigned a Universal Health Identifier (UHID)-a system which is intended to benefit patient and doctors, and may be useful to public health workers, but which has recently comeunder attack from privacy advocates.

On July 20th, a 17-

member National Committee on Vital and Health Statistics, part of the Department of Health and Human Services (HHS), began discussing implementation of the UHID. Committee members have indicated that theidentifier will probably taketheform of a number given to each citizen, much like the Social Security Number (SSN) currently used for tax and welfare records.

Indeed, it is that parallel which has some privacy advocates worried. "I predict that a health identifier would totally supplant the SSN within a decade of its adoption," says Robert Gellman, a privacy and information policy consultant in Washington, D.C. Gellman envisions a situation where “it may become impossible for any American to walk down the street without being forced to produce that [health ID] card on demand by a policeman." And as the card would belinked to medical records, patient privacy could be compromised.

TheUHID ismeant to streamline health care by making all of a patient's medical information accessible through a single referencepoint. Jonathan $\mathrm{R}$. Lumpkin, the Illinois Director of Public Health and a member of the committee, explains that a patient's records for are often kept in different locations-for example, a doctor's office and a diagnosticlaboratory. "Theidentifier would allow linking of records with a high degree of accuracy."

There is speculation that the system might also be useful to public health researchers who have to track down multiple records for studies. For example, it could be expanded into a nationwide database of heal th records that could be rendered anonymous and used for large-scale statistical analyses. Some private insurers and HMOsal ready maintain such databases on a smaller scale for internal studies. But committeemembers were quick to end such speculation. "Current technology al ready allowsfor the formation of a national heal th database, but therisk to privacy and thecost would make its creation a bad idea," says Lumpkin.

Last month, HHSSecretary Donna E. Shalala proposed new standards for protecting electronic medical information. Under HIPAA, Congress has until August 1999 to enact privacy protectionsfor such data, and if it failsto do so in that time, theHHSSecretary can enforce privacy protections by regulation.

Because it will not increase the availability of large data sets, theimpact of theUHID on public health research is likely to be modest, but some observers suggest even that claim may be overstated. According to Gellman, "Thereis potential, but no onehas offered any systematic documentation. Nor has anyone explored how similar goals could be achieved in other cheaper ways that do not have serious long-term effects on privacy and civil liberties."

The debate on how and when the UHID will be introduced is likely to continue for sometime. TheHHSwill haveto stagepublic hearings on theissue beforeformulating a specific policy, which will then bereleased for further public comment.

Alan Dove, New York

\title{
Japanese officials were aware of HIV in blood products
}

Fury has erupted in Japan over the contents of a tape recording of the first meeting held by the health ministry's AIDS study panel. The recording reveals that ministry officials were aware as early as 1983 that non-heat-treated blood products used to treat hemophiliacs may have been contaminated with HIV. Failure of the government and its scientific advisers to halt the use of such products led to more than 1,800 hemophiliacs contracting HIV during the 1980s, of which 400 have since died from AIDS.

Thetape was played during last month's trial of Akihito Matsumura, a former official of the Ministry of Health and Welfare (MHW), who is charged with professional negligence resulting in death. It was thought that minutes from the AIDS panel meeting did not exist; however, thetapewas one of several confiscated during oneof several police raids of the health ministry.

Matsumura is theonly ministry official to have been arrested in connection with the scandal. Three former presidents of Green
Cross Corporation-a leading pharmaceutical company that promoted the continued sales of non-heat-treated blood products_and Takeshi Abe, former vicepresident of Teikyo University and a hemophilia expert who headed the MHW's AIDS study group, are facing similar criminal charges (Nature M ed., 3; 480, 1997).

Abe, who pleaded not guilty to all charges, was heard on thetape saying

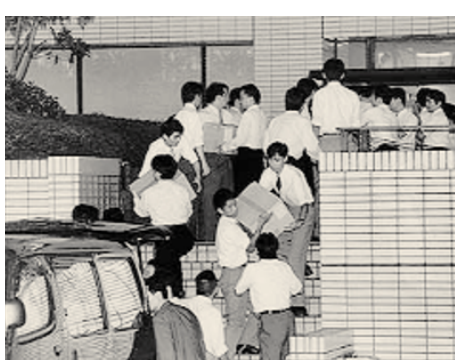

Police raid on the Japanese health ministry. the continued use of non-heat-treated coagulants. Moreover, Abeis suspected of receiving large 'donations' from Green Cross for deliberately delaying the clinical trials of heattreated products so that the company, which had the greatest market share of untreated blood productsin Japan, could continue sales.

Plaintiffs expressed their shock on hearing the panel members' conversations on ways to find 'countermeasures,' "we could have AIDS patientsin Japan at anytime," and expressing the feeling that he was "injecting poison" into his patients every day.

Hiscomments indicatethat hewasaware at the time of the risks associated with the use of untreated blood products, and despite proposals from scientists to abandon such products and switch to safer heat-treated solutions, Abe urged the panel to approve or rather a scapegoat, in the event that any AIDS patients emerged from the hemoone of Abe's hemophiliacs died from AIDS in 1983, thepanel had decided not to reveal the case, and instead announced in 1985 that Japan's first case of AIDS was a Japanese homosexual living in theUnited States. Asako SAEgUSA, Tokyo philiacs receiving thetreatment. Although 